\title{
Nietzsche and Callicles on Happiness, Pleasure, and Power
}

Kristian Urstad

\begin{abstract}
$\Lambda$ lthough there is no mention of him in his published works, there is little doubt that some of Nietzsche's most famous doctrines were inspired by the views expressed by the character Callicles in Plato's Gorgias. Though many have been keen to notice the resemblance between their moral, societal and political views, little, if any, attention has been given to the kinship between their views on happiness and its various components or relations. What I would like to try to do in this paper is to draw out these similarities. In so doing, I hope to also show where it is they might be seen to diverge in important and interesting ways.

Nietzsche clearly rails against the pursuit of pleasure where pleasure is understood as a particular sensation marked by the absence of any pain or discomfort. He, for instance, describes Epicurus, who conceived of pleasure (ataraxia) as the absence of all physical and mental discomfort, as "representing a state in which one is neither sick nor well, neither alive nor dead." Part of the reason for this is simply because he does not take such an account to be the correct construal of the experience of pleasure. For Nietzsche, pleasure cannot be divorced from pain, rather, they are "twins" one without the other. He states that pleasure and pain are "so knotted together that whoever wants as much as possible of the one, must also have as much as possible of the other..."3

Far from discouraging, or a recipe for misery, Nietzsche thinks this "play of resistance and victory", this overcoming of moments of pain and suffering, is how the feeling of joy (Lust) is attained. ${ }^{4}$ Joy, for him, seems to be closely akin to happiness, it is the conscious state of being man ultimately desires. ${ }^{5}$ What is important to see about Nietzsche's conception of joy or happiness is not only that it contains a component of pain ("in all joy pain is
\end{abstract}

1 Friedrich Nietzsche, The Will to Power, trans. by Walter Kaufmann and R. J. Hollingdale (New York: Vintage Books, 1967) 437.

${ }^{2}$ Friedrich Nietzsche, The Gay Science, trans. by Walter Kaufmann (New York: Random House, Inc., 1974), 338.

${ }^{3}$ Ibid., I, 12.

${ }^{4}$ Nietzsche, Will to Power, 699.

${ }^{5}$ Nietzsche's own terminology for happiness is far from rigid or consistent. Walter Kaufmann interprets him as holding that happiness is that state, not necessarily conscious, towards which all people strive, and joy, the conscious aspect of this state. See Nietssche: Philosopher, Psychologist, Antichrist, 4th ed. (New York: Vintage, 1974), Chapter 9. 
included"), but that it is intimately bound up with the notion of power. Nietzsche conceives of power as not only an overcoming of moments of suffering but as a total sort of self-overcoming, exhibited in those who are strong enough to maintain their mastery in the face of fervent desires and passions and ultimately in those who are able to sublimate their impulses, to "organize the chaos," and give "style" to their character. ${ }^{8}$ Before going any further with respect to Nietzsche's characterization of power, let me now turn to Callicles' views on pleasure and happiness.

Not unlike Nietzsche, Callicles also repudiates the notion of pleasure as a state free from pain or travail; and he does this at both the conceptual level and on a large scale, that is, as applied to life as a whole. At Gorgias, Socrates asks Callicles to confirm the following:

Then do you see what follows, that you say someone is distressed and enjoying at the same time, when you say he is thirsty and drinks??

Callicles' subsequent endorsement indicates that he upholds a remedial or replenishment conception of pleasure, one which involves the assuaging of a pain or the filling of a lack. Pleasure (drinking), in other words, entails the acceptance of distress (thirst), since the pleasure is proportional to the magnitude of the lack that is being replenished.

But, for Callicles, pleasure is not only connected to the experience of pain at the conceptual level of desire-satisfaction. He also takes pain or distress as part and parcel of his conception of the happy life. Beginning at Gorgias 493a, Socrates recounts to Callicles a myth he heard once from a wise man, where he connects up the soul with desires in the person living licentiously with a leaky jar which is insatiable because it can never be filled. He presumes that the life of the intemperate man, he who tries to keep his leaky jars full, is one which requires constant work, turmoil and suffering. The temperate man, on the other hand, having filled up his sound jars, needs to give no further thought to them and can relax and rest easy. He concludes by asking Callicles,

Now if this is how each man's life is, do you say that the intemperate man's life is happier than the orderly man's? ${ }^{10}$

${ }^{6}$ Nietzsche, Will to Power, 658; see also Thus Spoke Zarathustra, trans. by Walter Kaufmann, in The Portable Nietzsche (New York: Penguin Books, 1976), IV 19.

7 Nietzsche, Will to Power, 688; Daybreak, trans. by R. J. Hollingdale (Cambridge: Cambridge University Press, 1997), 113; On the Genealogy of Morals, trans. by Walter Kaufmann, in Basic Writings of Nietzsche (New York: Modern Library, 2000), III 10.

8 Nietzsche, Gay Science, 290.

9 Plato, Plato: Gorgias, intro. And commentary by E.R. Dodds (London: Oxford University Press, 1959), 496e5.

${ }^{10}$ Ibid., 493a. (italics added) 

explanation:

Callicles' response is an emphatic yes. He offers the following

For that one who has filled up has no pleasure at all any more. It's what I was saying just now - living like a stone once he has filled up, with no more enjoyment or distress. No; living pleasantly is in this - in having as much as possible flowing in. ${ }^{11}$

What Callicles appears to be saying here is that, if one, like himself, opts for a life full of desires, then, within that life, one cannot have pleasure without pain, that they will be present in somewhat equal proportions. Indeed, he explicitly acknowledges this when he tells Socrates that when one has been "filled up", there is "no more enjoyment or distress (lupe)". What Callicles is advocating is a life where one is continually replenishing, and not simply replenished (and so experiencing neither pleasure nor pain), where one is constantly emptying and filling, and not simply filled. The happy man then, according to Callicles, is not someone who experiences pleasures and no pains; rather, he knows very well that his objective of "having as much as possible flowing in" demands a requisite amount of accompanying pain or distress. Thus, though they differ in important details, at the most basic level both Nietzsche and Callicles take the good life to be one marked by a significant amount of pain, discomfort, and labor.

Callicles' reference to "living like a stone" is interesting and brings us, I believe, to another point of similarity between his views and those of Nietzsche, especially with respect to the latter's outlook on, not only adherents of religion - in particular, of Buddhism - but what he calls the "last man". Nietzsche spurns the Buddhist's aim of Nirvana because he sees it in part as a yearning for the complete extinction of all consciousness and for the negation of life, will, and activity. ${ }^{12}$ The Noble Truths of Buddhism declare that life is suffering. Suffering comes from passion and desire, which ought, according to the Buddhists, to be eliminated. Nietzsche sees this as culminating in the attempt to extirpate the passions, a state which, as we have seen, he vehemently opposes. Equally objectionable for Nietzsche is the so-called "last man", a term he uses to describe the opposite type of individual to his superior and ideal being, the Übermensch, ${ }^{13}$ and a class to which he thinks the majority of modern men belong. The last man does not seek an active life, but a secure and comfortable one. He is content to lead a life of passive acquiescence and he wants to avoid pain at all costs. He has few preferences and no big desires; he is, in effect, apathetically neutral. ${ }^{14}$ Nietzsche sees in both forms of life signs of weakness and resignation. Nirvana and the comfortable existence of the last

11 Ibid., 494a-b. (italics added)

12 Friedrich Nietzsche, The Birth of Tragedy, trans. by Walter Kaufmann, in Basic Writings of Nietzsche (New York: Modern Library, 2000), 7.

${ }^{13}$ Nietzsche, Zarathustra, Prologue 3,4.

${ }^{14}$ Ibid., Prologue 5. 
man are not authentic forms of happiness but substitutes desired by the weak and insipid who are incapable of achieving that state of joyous power acquirable by stronger individuals. ${ }^{15}$ Their fears and inability to master their drives and desires lead both the Buddhists to resign themselves to another (perfectly painless) world and the last men to settle for the comfortable and secure life.

Callicles' outlook is eerily similar in this regard. A little earlier in their discussion, Socrates rhetorically asks Callicles if it's wrong to say that those who need nothing are happy, whereupon he receives the following answer:

Yes, for in that case stones and corpses would be happiest. ${ }^{16}$

There is no reason to take Callicles' reference to corpses and stones here, and at aforementioned 494a, merely as a kind of shock sarcasm. He is serious about likening those who restrict or abstain from their desires and passions with dead and inanimate objects. According to Callicles, such perceived anemia is definitely not the mark of a superior individual, and falls far short of what it takes to achieve the good and full human life. He defines the superior person as one who is not only wise about public affairs, but who is courageous and able to accomplish what they want without faltering through weakness or softness of soul. ${ }^{17}$ Moreover, it is someone who is able to:

...let his appetites grow as large as possible and not restrain them, and when these are as large as possible, he (has) the power to serve them, because of his bravery and wisdom, and to fill them with whatever he has an appetite for at any time. ${ }^{18}$

What the superior person rejects are the virtues of temperance and self-rule (sophrosyne, enkrateia), conventionally understood. ${ }^{19}$ Callicles calls adherents of conventional temperance fools, for only a fool would voluntarily fail to satisfy a satiable desire. ${ }^{20}$ The superior individual, on the other hand, is enslaved to nothing at all, ruled by no one, not even by himself. He cultivates and gratifies his desires to the fullest in accordance with the dictates of natural justice, dictates grounded in nature (phusis), entirely disembodied from conventional (nomos) morality. ${ }^{21}$ Because the majority of people are overwhelmed by large desires or simply incapable of living like this, they invent

${ }^{15}$ Friedrich Nietzsche, Beyond Good and Evil: Prelude to a Philosophy of the Future, trans. by Walter Kaufmann (New York: Vintage, 1966), 225; Zarathustra, Prologue 5.

16 Plato, op cit., 492e.

17 Ibid., 491a-b.

18 Ibid., 491e-492a.

${ }^{19} \mathrm{Ibid} ., 491 \mathrm{~d}-\mathrm{e}$.

${ }^{20}$ Ibid., 491e.

${ }^{21}$ Ibid., 483a-484b. 
bogus virtues like temperance and self-control, praise them, and champion desire-restricted or ascetic accounts of happiness. Not unlike Nietzsche, Callicles sees in the many weakness, fear and resentement. Such desirerestricting virtues are merely symptoms of sickliness, the "lack of manhood,"22 of their convention-bound inventors. Their happiness is but a substitute desired by the weak who are incapable of achieving that state whereby one has cast off all unnatural constraints and given free rein to one's desires, a state which they, too, would prefer if they had the strength and courage to attain it.

This last matter brings us to a final point of similarity between Nietzsche and Callicles, what they both take to be the supreme virtue ${ }^{23}$ and an indispensable means to happiness - courage. For Nietzsche, courage seems to be not so much about simply overcoming moments of fear. It has more to do with overall assertiveness and execution, with an overflowing sense of resolution and mission in life: 24

How does one become stronger? - By coming to decisions... and by clinging tenaciously to what one has decided... (when one fails) to listen to one's most personal requirements...(when one) underestimates oneself...this lack of reverence for oneself revenges itself through every kind of deprivation:... freedom, firmness, courage.....25

Part and parcel of such resolution is the ability to pursue one's ideals not only despite the dangers of failure, but despite the perception of being shamed and ridiculed. The courageous person is not deterred from his goal by social expectations and shame tactics, his constitution is such that he's able to proceed despite them. This seems to be part of Zarathustra's counsel when he exclaims "Make yourself hard!"26

Callicles' conception of courage is quite comparable to Nietzsche's. For him, courage also has to do with the overall execution and single-minded pursuit of the superior person's large desires and goals. To reiterate:

...the man who is to live rightly should let his appetites grow as large as possible and not restrain them, and when these are as large as possible, he must have the power to serve them, because of his bravery (andreia) ....27

22 Ibid., $492 \mathrm{a} 8$.

${ }^{23}$ Nietzsche, Zarathustra, IV, 3. 2; Plato, op cit., 492a.

24 See Robert Solomon, Living With Nietzsche (Oxford: Oxford University Press, 2003), 148-9, for more on this aspect of courage in Nietzsche.

${ }^{25}$ Nietzsche, Will to Power, 918.

${ }^{26}$ Nietzsche, Zarathustra, iii. 12. 29.

${ }^{27}$ Plato, op cit., 491e-492a. (italics added) 
The many, because of their unmanliness, do not have the power to follow through with their desires and projects; and so, concealing their cowardice and powerlessness, they resort to shaming (e.g. calling intemperance bad) those who are courageous enough to do so. ${ }^{28}$ The Calliclean individual however is "brave", that is, "capable of fulfilling what they intend" and someone who, inverting the words of Zarathustra, doesn't give in because of "softness of soul." ${ }^{29}$ Not unlike Nietzsche then, courage, according to Callicles, is typified in the individual who remains resolute in his own path and who never weakens from softness of spirit.

Where Nietzsche and Callicles differ most significantly is in their respective notions of power. This may not be so obvious however, at least upon a superficial reading. For both provide us with striking examplars of warrior men whose exercise of power involves military power, such as, in the case of Nietzsche, Napoleon and Caesar, and in the case of Callicles, Xerxes and Heracles. And both employ animal imagery, in particular, the image of the lion, to express power. Nietzsche, for instance, speaks of the "magnificent blond beast that prowls in search of booty and victory,"30 and Callicles of the lion whom society vainly seeks to tame.31 However, as briefly mentioned at the outset, Nietzsche does not have in mind anything resembling political power, nor something like power over other people. ${ }^{32}$ Indeed, he sees in the aspiration to find one's own power through the oppression of others a sign of petty weakness:

I have found strength where one does not look for it; in simple, mild and pleasant people, without the least desire to rule - and conversely, the desire to rule has often appeared to me as a sign of inward weakness.... ${ }^{33}$

It is, moreover, the ruler or dictator who is apt to become the slave of his passions. Since he cannot rule himself, he can hardly be said to be powerful. To reiterate, for Nietzsche, true power, which is partly embodied by his Zarathustra, involves the overcoming of oneself, it consists in the mastery,

28 Ibid., $492 \mathrm{~b}$

29 Ibid., 491b (italics added); also see Dodds, 1959, Appendix, 390, for a brief discussion on courage in Callicles and Nietzsche.

30 Nietzsche, Genealogy of Morals, i, II.

31 Plato, op cit., 483e-484a.

32 Gilles Deleuze is adamant that to read Nietzsche's will to power as a straightforward desire for power or domination is to misinterpret his thought. "In this way the will to power is essentially creative and giving: it does not aspire, it does not seek, it does not desire, above all it does not desire power. It gives:..." See Nietssche \& Philosophy (New York: Columbia University Press, 2006), 85. Deleuze quotes Nietzsche's Zarathustra: "Desire for power: but who shall call it desire...Oh who shall find the rightful baptismal and virtuous name for such longing! 'Bestowing virtue' - that is the name Zarathustra once gave the unnameable." See Nietzsche, Zarathustra, III, "Of the Three Evil Things."

${ }^{33}$ Kaufmann, op cit., 252, X 412. 
through sublimation, of one's destructive impulses and desires, with the goal of giving style to one's character and becoming noble in one's tastes. ${ }^{34}$

Callicles also takes power to be an important constituent of happiness, ${ }^{35}$ however, he clearly conceives of it as rule or domination over others, as a kind of bully's power. His examples of natural right, for instance, all involve dominance by brute strength and political (Machiavellian) ingenuity. ${ }^{36}$ He makes numerous meritorious allusions and references to tyrants and rulers throughout his discussion, ${ }^{37}$ without any indication that we are supposed to understand their power as anything but a kind of dominion over others. A further sign that Callicles is thinking of power along these lines is the blatant confusion he shows at Socrates' question concerning whether or not the superior man ought not only rule over others but also rule over bimself, that is, those desires within him. ${ }^{38} \mathrm{He}$ asks Socrates three times what he means by this question, which is not at all surprising if, as suggested, he understands power as nothing but rule over others. In fact, Socrates goes on to warn Callicles, through his sieve-myths, that the soul of the one who practices no self-rule and gives free reign to his desires, will be susceptible to persuasion and loss of stability and control..$^{39}$ Socrates is not questioning the external control that the Calliclean individual might be said to possess over others and the environment, but the internal control that he supposedly possesses over himself and his particular desires. In what sense is Callicles' superior individual internally free from the effects of the pleasures and satisfactions involved in his excessive living? What are the inner resources by which his largely unrestrained life is maintained? Some years earlier, Democritus had insisted upon the important unification or symbiosis between certain external virtues or strengths and internal ones:

The brave man is superior not only to his enemies but also to pleasure. Some men are master of cities but slave to women..$^{40}$

Callicles is clear on, and unashamedly confident about, the successful execution of the kind of power the superior man has over others, but completely silent in attributing to him any concern, let alone awareness, for the inner, psychological element in this connection. Callicles then appears ignorant of any insight that genuine power involves, as it does for Nietzsche, a kind of complete or holistic self-mastery. Well aware of Callicles' views, perhaps this

34 Nietzsche, Daybreak, 202, 348.

${ }_{35}$ Plato, op cit., 492a-c.

36 Ibid., 483d.

${ }^{37}$ Ibid., 483dff, 492b.

38 Ibid., 491d.

39 Ibid., 493c. Also see Kristian Urstad, "Freedom and Happiness in Callicles and Socrates," in Lyceum, 9:1 (2007) for further analysis of Socrates' sieve-myths and their warning to Callicles.

${ }^{40} \mathrm{H}$. Diels and W. Kranz eds., Die Fragmente der Vorsokratiker, 3 volumes (Berlin: Weidmann, 1996), B214. 
was seen as a weakness in his progenitor's outlook that Nietszche, in the development of his own position, was able to learn from. ${ }^{41}$

I have tried to set forth some evidence for the claim that Nietzsche's doctrines on happiness and its constituents were in some measure inspired by some of the relevant views put into the mouth of Callicles by Plato in his Gorgias. There is, I have argued, strong alignment between their conceptions of happiness or the good life, pleasure, and courage. While superficially they appear somewhat close in their account of power, Nietzsche clearly deviates from Callicles, giving a much more subtle, penetrating and comprehensive analysis - an analysis Callicles appears not to be open to.

Department of Pbilosophy, University of the Fraser V alley, Canada

\section{References}

Deleuze, Gilles, Nietzsche \& Philosophy (New York: Columbia University Press, 2006).

Diels, H. and W. Kranz eds., Die Fragmente der Vorsokratiker, 3 volumes (Berlin: Weidmann, 1996).

Kaufmann, Walter, Nietzsche: Pbilosopher, Psychologist, Antichrist, 4th ed. (New York: Vintage, 1974).

Nietzsche, Friedrich, Beyond Good and Evil: Prelude to a Pbilosopby of the Future, trans. by Walter Kaufmann (New York: Vintage, 1966). Daybreak, trans. by R. J. Hollingdale (Cambridge: Cambridge University Press, 1997).

On the Genealogy of Morals, trans. by Walter Kaufmann, in Basic Writings of Nietzsche (New York: Modern Library, 2000).

The Birth of Tragedy, trans. by Walter Kaufmann, in Basic Writings

of Nietzsche (New York: Modern Library, 2000).

The Gay Science, trans. by Walter Kaufmann (New York: Random House, Inc., 1974).

${ }^{41}$ Little has been said about it, but we might wonder about the specifically political implications of this meaning of power in Nietzsche. Though there is by and large an absence of any identifiable political doctrines in his texts, Nietzsche does occasionally speak (especially in Beyond Good and Evil) about a 'grand politics', a 'new caste' of superior beings and an 'aristocratic society'. He is much more explicit moreover, in his rejection of the idea of equal rights, socialism and modern liberal democracry. Prima facie, the political connotations here suggest competition, domination, exploitation or power of overs (as fundamental to the development of a higher existence). But this, it seems to me, is misleading. In line with the central exegesis on power, I suggest that Nietzsche's seeming politics of domination and his use of the term aristocracy be seen primarily within the aesthetic context of self-perfection, self-cultivation and restraint. It is perhaps suggestive that the virtues Nietzsche praises are not so much political virtues but personal ones - honesty, courage, generosity and politeness, being the cardinal four. Even strength for him is rarely measured in terms of physical strength and prowess, but as health, and as such, a personal, not a competitive virtue. In this regard, Nietzsche seems to follow his intellectual foe and admirer, Socrates, in so far as he largely disregards involvement in politics while making individual virtue and the good of one's soul the central concern. 
The Will to Power, trans. by Walter Kaufmann and R. J. Hollingdale (New York: Vintage Books, 1967).

Thus Spoke Zarathustra, trans. by Walter Kaufmann, in The Portable Nietasche (New York: Penguin Books, 1976).

Plato, Plato: Gorgias, intro. And commentary by E.R. Dodds (London: Oxford University Press, 1959), $496 \mathrm{e} 5$.

Robert Solomon, Living With Nietzsche (Oxford: Oxford University Press, 2003). 